\title{
Effects of foliar versus soil water application on ecophysiology, leaf anatomy and growth of pineapple
}

\author{
P.A. Demarco ${ }^{1}$, M.D. Gómez Herrera ${ }^{2}$, A.M. Gonzalez ${ }^{3}$ and P. Alayón Luaces ${ }^{1, a}$ \\ ${ }^{1}$ Cátedra de Fruticultura, Departamento de Producción Vegetal, Facultad de Ciencias Agrarias, Universidad Nacional del \\ Nordeste, Sargento Cabral 2131 (3400) Corrientes, Argentina \\ ${ }^{2}$ Instituto de Química Básica y Aplicada del Nordeste Argentino - IQUIBA NEA (UNNE-CONICET), Facultad de Ciencias \\ Exactas Naturales y Agrimensura, Universidad Nacional del Nordeste, Avenida Libertad 5470, (3400) Corrientes, Argentina \\ ${ }^{3}$ Instituto de Botánica del Nordeste - IBONE (UNNE-CONICET), Facultad de Ciencias Agrarias, Universidad Nacional del \\ Nordeste, Sargento Cabral 2131 (3400) Corrientes, Argentina
}

\section{Summary}

Introduction - In the subtropics, pineapple [Ananas comosus (L.) Merr.] can be grown in plastic greenhouses to avoid low temperature, which is the main limiting factor to production outside of the tropics. Foliar water application and subsequent evaporative cooling can help avoid excessive leaf temperatures in greenhouses during the hot seasons. The effects of foliar versus soil irrigation on ecophysiology, leaf anatomy and leaf temperature of pineapple in protected culture were tested to determine if the crop could receive sufficient irrigation to avoid plant stress solely from misting the foliage. Materials and methods - Relative water content, relative chlorophyll content, normalized difference vegetation index, membrane stability, and cross sectional leaf anatomy were measured at periodic intervals. Pineapple plants were subjected to soil irrigation, misting and drought. At the beginning and at the end of the experiment, total leaf area, plant biomass and assimilate partitioning to leaves, stems and roots were measured. Results and discussion - The normalized difference vegetation index revealed differences among treatments after fifteen days without irrigation. Pineapple plants endured thirty days of water stress without membrane damage. Plants irrigated by applying water only to the leaves did not receive adequate water amounts and showed similar signs of drought stress as those of the non-irrigated treatment. Conclusion - Based on ecophysiological, anatomical and growth responses, soil water application alone is sufficient for avoiding water stress and excessively high leaf temperatures of pineapple plants grown in protected culture in the subtropics, whereas only misting the leaves does not provide adequate water supply to prevent water stress.

Keywords

Ananas comosus, Argentina, drought stress, leaf temperature, NDVI

a Corresponding author: palayonluaces@yahoo.com.

\section{Significance of this study}

What is already known on this subject?

- Pineapple plants exhibit phenotypic plasticity in the anatomical structure of their leaves in different growing conditions.

\section{What are the new findings?}

- Pineapple plants endured thirty days of water stress without membrane damage. Soil water application alone is sufficient for avoiding water stress of pineapple plants grown in protected culture in the subtropics.

What is the expected impact on horticulture?

- The water supply solely by soil application in pineapple crops in protected culture maintains plant growth and prevents excessively high leaf temperatures during hot seasons in subtropical regions.

\section{Introduction}

Pineapple [Ananas comosus (L.) Merr. var. comosus] is a perennial tropical herbaceous plant in the Bromeliaceae family. It is the most economically important species of this family and grown commercially in many tropical and subtropical countries (Botella and Smith, 2008). Climate affects the productivity and quality of pineapple fruit. Crop development occurs in areas with temperatures from 18 to $45^{\circ} \mathrm{C}$, with the optimum between 21 and $27^{\circ} \mathrm{C}$. Low temperature is the main limiting factor for the development of this crop. Growth is delayed between 10 and $16^{\circ} \mathrm{C}$ (Carvalho et al., 2005). Protected culture under plastic cover (greenhouses) can eliminate the potential for low temperature stress. However, management strategies for commercial pineapple production in protected culture still require studies to optimize plant growth and yield.

Several studies have evaluated greenhouse production of pineapple in the subtropical province of Corrientes, Argentina. One of these studies found that pineapple plants grown under plastic cover produce fruits earlier than plants grown in the field (González Leguizamón et al., 2013). However, final fruit size was smaller in protected culture compared to that of the same variety in the field. Therefore, it is necessary to adjust cultivation techniques to get plants with higher biomass at the time of floral induction and hence the production of larger fruits as there is a 
direct relationship between plant and fruit sizes (Py, 1969). Pineapple plants exhibit phenotypic plasticity in the anatomical structure of their leaves, with differences between greenhouse-grown and field-grown plants. In protected culture, there is often a greater dry matter accumulation of pineapple than in the field, probably associated with environmental conditions in the greenhouse, such as high relative air humidity, which effects leaf physiology and net carbon assimilation (Ebel et al., 2016). Plants with crassulacean acid metabolism (CAM), such as pineapple, minimize water loss through nocturnal carbon assimilation when temperatures are low, which is reflected in low evapotranspiration (Wai et al., 2017). The mesophyll of pineapple leaves is composed of two clearly differentiated zones: a dark zone formed by chlorophyll parenchyma where the vascular bundles and fibrous caps (sclerenchyma) are located, and a clear area composed of aquiferous parenchyma that is a natural reservoir of water in the leaves (Derwidueé and González, 2010).

Many species in the Bromeliaceae are epiphytic and obtain water and nutrients by surface absorption via numerous multicellular trichomes covering the leaves and stem (Martin, 1994; Poczai and Hyvönen, 2017). In terrestrial species, such as pineapple, trichomes are tiny hair-like structures that surround the stomata (Lobo et al., 2017); the leaf architecture is well suited for collection of heavy dew that condenses on leaves and drains into the leaf whorl. At the base of the leaf whorl, water is absorbed by axillary roots, which develop in response to water and nutrients in leaf axils, and leaf trichomes (Sakai and Sanford, 1980). Py (1969) noted that trichomes at the base of pineapple leaves play an important role in water absorption. There is little published information on the effects of water deficit on vegetative growth, flowering or fruiting of pineapple (Carr, 2012).

As with other members of the Bromeliaceae, misting of the leaves may be an effective method of water delivery that also can serve to prevent leaf overheating through evaporative cooling (Shen and Chen, 2012). In the subtropics, temperature inside the greenhouse may reach 43 to $45{ }^{\circ} \mathrm{C}$ at summer middays, resulting in overheating of the leaves. The most efficient method of applying water and maintaining leaf temperature to avoid stress of pineapple plants grown in protected culture has not been elucidated yet. The hypothesis of this study was that pineapple plants can receive sufficient water supply to avoid stress solely from misting their foliage. To test this hypothesis, we compared foliage misting with soil water application on the ecophysiology, leaf anatomy and temperature, and growth of pineapple plants in protected culture in the subtropics.

\section{Materials and methods}

The experiment was conducted at the Experiment Station of the Faculty of Agricultural Sciences, Universidad Nacional del Nordeste in Corrientes, Argentina (lat.: 27 $28^{\prime} 27^{\prime \prime} S$, long.: $27^{\circ} 28^{\prime} 27^{\prime \prime}, 70 \mathrm{~m}$ a.s.l.) in a greenhouse (5.5 m high $\times 25 \mathrm{~m}$ long $\times 8 \mathrm{~m}$ wide) with a $150 \mu \mathrm{m}$ thick polyethylene covering (Agrotileno, IPESA \& Rio Chico S.A., Buenos Aires, Argentina). The greenhouse was ventilated manually opening the side panels when air temperature exceeded $23^{\circ} \mathrm{C}$; minimum greenhouse air temperature was above $0{ }^{\circ} \mathrm{C}$ during the entire experiment. Temperature and humidity were recorded using datalogger sensor (DAF-10 Data-Logger, Schwyz, China).

Pineapple plants of cultivar Smooth Cayenne were grown from 500-600 g suckers during six months before beginning the experiment to allow adequate root development. Plants were then transplanted into 5-L plastic pots containing Grow
Mix Multipro ${ }^{\circledR}$ medium which is composed by peat moss at $85 \%$ to $90 \%$ (Terrafertil, Buenos Aires, Argentina).

Plants were divided into three treatments: 1) Water applied directly to the soil (Soil Irrigation), 2) Misting leaves without applying water to the soil (Misting), and 3) No water applied (Drought). Little or no water dripped from the leaves to the soil in the Misting treatment. In the Soil Irrigation treatment, the soil water content was measured daily with a thermohygrometer (Hygrotherm, TFA, Germany) and water was applied manually so that the soil water content remained at field capacity. In the Misting treatment, water was applied individually to leaves of each plant to the drip point by misting the foliage with a hand-sprayer taking care to ensure that little water (no more than a few drops) dripped from the leaves to the soil. The experiment was arranged as a completely randomized design with a sufficient number of plants to allow destructive sampling over time with three replicates per treatment at each sampling time.

For plant ecophysiology measurements, four fully elongated leaves, referred to as 'D' leaves (Py, 1969), were harvested from each replicate. Relative water content (RWC) was determined by removing a $2 \mathrm{~cm}^{2}$ disc from the centre of the leaf, measuring its fresh weight (FW), submerging it in water for $8 \mathrm{~h}$ and measuring its turgid weight (TW). The leaf disc was then dried at $70^{\circ} \mathrm{C}$ to a constant weight and dry weight (DW) was determined. The RWC was calculated as:

$$
\text { RWC }(\%)=(F W-D W) /(T W-D W) \times 100 .
$$

The leaf chlorophyll index (LCI) was determined with a SPAD meter (model 502, Minolta Inc., Osaka, Japan) from five leaves per replicate.

The normalized difference vegetation index (NDVI), calculated as the ratio of intensities in the visible and near infra-red wavelengths of the electromagnetic spectrum, was determined in real-time with a GreenSeeker ${ }^{\circledR}$ Handheld Crop Sensor (Trimble Ag Field Solutions, Sunnyvale, CA, USA).

The membrane stability index (MSI) was determined as described by Sullivan (1972), whereby the electrical conductivity of a solution of deionized water containing a $2 \mathrm{~cm}^{2}$ leaf disc was determined with a portable conductivity meter (AD-31 EC/TDS, Adwa Kft., Romania).

Leaf samples were collected for anatomical analyses at the beginning of the experiment and after 15, 30 and 45 days (the last day of the experiment). The central portion of the leaf was treated with histological fixative (FAA: 70\% ethanol, formaldehyde and acetic acid, 90:5:5) and 15 to $25-\mu \mathrm{m}$ thick cross-sections were made by hand using a microtome blade. Leaf sections were stained with safranin and Astra blue. Digital micrographs of the lamina, chlorophyll parenchyma, and aquiferous parenchyma were observed and photographed with a compound stereo microscope equipped with a digital camera. The cross-sectional thickness of each cell type in the leaf was quantified from digital images using Image ${ }^{\circledR}$ software.

At the end of the experiment thermal digital images of each plant were taken with a thermal camera (model C2, Flir Systems, Inc., Wilsonville, OR, USA) as an indication of the temperature of the surface of the foliage.

Total leaf area (LA) was measured as described by Rebolledo et al. (2005), whereby LA was estimated from the total leaf fresh weight (FW) using the formula:

Foliar area $\left(\mathrm{cm}^{2}\right)=34.6087+5.65202 \times$ FW 
Plant biomass and assimilate partitioning (AP) were determined by harvesting each plant and individually weighing leaves, stems, and roots to obtain fresh weight (FW). Plant organs were then dried in an oven at $70{ }^{\circ} \mathrm{C}$ to a constant weight and leaf, stem, and root dry weights were determined. The AP was expressed as $g$ of leaves, stems, or roots per total plant DW (DW plant ${ }^{-1}$ ).

Statistical differences among treatments were determined by one-way analysis of variance (ANOVA) using InfoStat ${ }^{\circledR}$ software (Di Rienzo et al., 2012) and means were compared by Tukey's Honestly Significant Difference (HSD) test at $\mathrm{P} \leq 0.05$.

\section{Results}

\section{Leaf chlorophyll index (LCI)}

There were no differences in the (LCI) index among treatments until day 30. At 45 days were significant differences between Soil Irrigation and Misting treatments (Table 1).

\section{Normalized difference vegetation index (NDVI)}

From 15 days after starting the experiment the NDVI was significantly higher for Soil Irrigation than for Drought and Misting treatments, which did not significantly differ between them (Table 1).

\section{Relative water content (RWC)}

At the beginning of the experiment, the RWC in all treatments was between $77.5 \%$ and $79.8 \%$ (Table 1). From day 15 RWC was significantly higher in the Soil Irrigation treatment than in the other ones studied. On day 45 , there was a significant difference in the RWC among all three treatments with the Soil Irrigation treatment having the highest value and the drought treatment having the lowest value (Table 1).

\section{Membrane stability index (MSI)}

There were no differences in MSI among treatments for the first 30 days of the experiment. At 45 days, the MSI of the Soil Irrigation treatment was superior to that of the Misting and Drought treatments (Table 1). At that time, cell membranes of plants of these latter treatments showed damages.

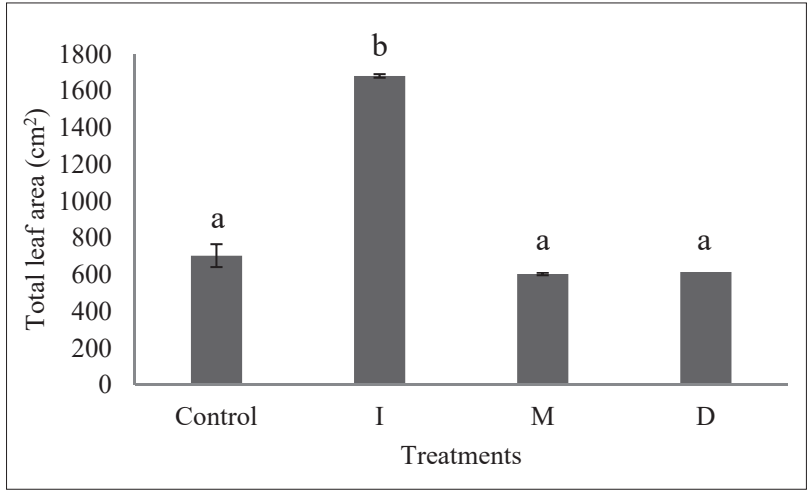

FigurE 1. Total leaf area of 'Smooth Cayenne' pineapple plants, at the beginning (control) and the end (45 days) of the experimental period for soil irrigation (I), misting (M) and drought (D) treatments. Each value represents the mean \pm SE of three replicates; same letter per treatment was not significantly different according to Tukey HSD test $(\mathrm{P} \leq 0.05)$.

\section{Total leaf area (LA), biomass and assimilate partitioning (AP)}

The LA of plants in the Soil Irrigation treatment increased 2.45 fold within the experimental period and on day 45 was significantly larger than that of plants in the Misting or Drought treatments (Figure 1). Total leaf area in the Misting and Drought treatments did not increase during this experiment, probably due to the short experimental period ( 45 days) for leaves development under the water restriction.

Dry weight increased in Soil irrigation and Drought after 45 days of treatment compared with initial conditions. However, no differences were found on misting treatment and the control (Figure 2A). According to the partitioning, there was no difference in roots among the treatments after 45 days. Although, after this period significant differences were found in soil irrigation leaves compared with Misting, Drought treatments and the control. Besides, an increment on stem dry weight was found on Drought treatment at 45 days in comparison with initial conditions (Figure 2B).

TABLE 1. Leaf chlorophyll index (LCI; spad units), normalized difference vegetation index (NDVI), relative water content (RWC; \%) and cell membrane stability index (MSI; \%) of pineapple plants exposed to drought (D), misting (M) or soil irrigation (I). Means followed by the same letter in columns, per treatment, were not significantly different according to Tukey HSD test $(\mathrm{P} \leq 0.05)$.

\begin{tabular}{lccccc}
\hline & & \multicolumn{3}{c}{ Time } \\
\cline { 2 - 5 } & Treatments & Day 0 & Day 15 & Day 30 & Day 45 \\
\cline { 2 - 5 } & & Mean \pm SD & Mean \pm SD & Mean \pm SD & Mean \pm SD \\
\cline { 2 - 5 } LCI & D & $48.8 \pm 6.3 \mathrm{a}$ & $39.7 \pm 4.1 \mathrm{a}$ & $43 \pm 7.8 \mathrm{a}$ & $57 \pm 6.2 \mathrm{ab}$ \\
& $\mathrm{M}$ & $48.8 \pm 7.4 \mathrm{a}$ & $50.6 \pm 3.7 \mathrm{a}$ & $42.5 \pm 4.5 \mathrm{a}$ & $50.4 \pm 0.5 \mathrm{a}$ \\
& $\mathrm{I}$ & $52.6 \pm 6.5 \mathrm{a}$ & $51.4 \pm 9.1 \mathrm{a}$ & $58.4 \pm 7.2 \mathrm{a}$ & $64.9 \pm 5.7 \mathrm{~b}$ \\
\hline $\mathrm{NDVI}$ & $\mathrm{D}$ & $0.62 \pm 0.01 \mathrm{a}$ & $0.51 \pm 0.03 \mathrm{a}$ & $0.46 \pm 0.02 \mathrm{a}$ & $0.44 \pm 0.02 \mathrm{a}$ \\
& $\mathrm{M}$ & $0.62 \pm 0.01 \mathrm{a}$ & $0.43 \pm 0.07 \mathrm{a}$ & $0.46 \pm 0.02 \mathrm{a}$ & $0.42 \pm 0.01 \mathrm{a}$ \\
& $\mathrm{I}$ & $0.62 \pm 0.01 \mathrm{a}$ & $0.62 \pm 0.03 \mathrm{~b}$ & $0.62 \pm 0.03 \mathrm{~b}$ & $0.59 \pm 0.02 \mathrm{~b}$ \\
\hline RWC & $\mathrm{D}$ & $79.4 \pm 5.6 \mathrm{a}$ & $72.2 \pm 5.2 \mathrm{a}$ & $76.4 \pm 2.5 \mathrm{a}$ & $59.5 \pm 2.7 \mathrm{a}$ \\
& $\mathrm{M}$ & $77.5 \pm 2.5 \mathrm{a}$ & $75.6 \pm 2.9 \mathrm{a}$ & $71.8 \pm 6.3 \mathrm{a}$ & $70.9 \pm 2.4 \mathrm{~b}$ \\
& $\mathrm{I}$ & $79.8 \pm 1.2 \mathrm{a}$ & $91.7 \pm 2.2 \mathrm{~b}$ & $97.8 \pm 2.3 \mathrm{~b}$ & $87.5 \pm 1.9 \mathrm{c}$ \\
\hline MSI & $\mathrm{D}$ & $50.8 \pm 10.4 \mathrm{a}$ & $37.4 \pm 11.2 \mathrm{a}$ & $44.9 \pm 7.2 \mathrm{a}$ & $11.8 \pm 10 \mathrm{~b}$ \\
& $\mathrm{M}$ & $56.9 \pm 3.9 \mathrm{a}$ & $36.6 \pm 9.2 \mathrm{a}$ & $34.6 \pm 7.3 \mathrm{a}$ & $23.1 \pm 21.1 \mathrm{~b}$ \\
& $\mathrm{I}$ & $53.1 \pm 3.7 \mathrm{a}$ & $43.7 \pm 6.5 \mathrm{a}$ & $45 \pm 6.3 \mathrm{a}$ & $54.2 \pm 6.7 \mathrm{a}$ \\
\hline
\end{tabular}




\section{Leaf anatomy}

At 30 days after beginning of the treatments, the percentage of aquiferous parenchyma (AqP), measured in the leaf cross section was significantly lower in the Misting treatment compared to the Soil Irrigation treatment (Table 2). At 45 days, the percentage of aquiferous parenchyma was significantly different among the three treatments (Table 2, Figure 3). The water content of the AqP was high until 30 days after treatments started; thereafter, it began to be continuously depleted up to the end of the experiment (day 45).

\section{Thermal images}

After 45 days, canopy temperatures were 30.9 to $31.0{ }^{\circ} \mathrm{C}$ for plants in the Soil Irrigation treatment, 33 to $34{ }^{\circ} \mathrm{C}$ for plants in the Misting treatment and 37.5 to $37.7^{\circ} \mathrm{C}$ for plants in the Drought treatment (Figure 4).

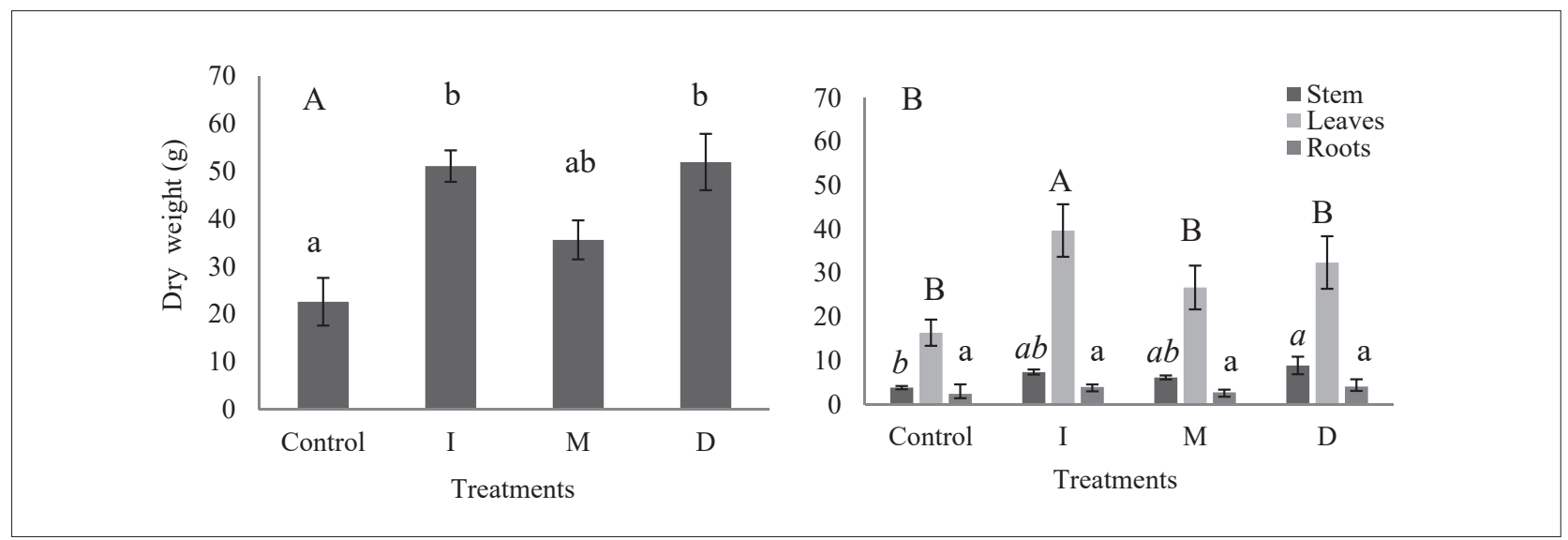

FiguRE 2. (A) Total plant dry weight and (B) assimilate partitioning (AP) on dry weight base of 'Smooth Cayenne' pineapple plants irrigated by applying water to the soil (I), misting the foliage (M) or not irrigated (drought stressed; D) at the beginning of the study (control) and after 45 days. Each value represents the mean \pm SE of three replicates, same letter per treatment was not significantly different according to Tukey HSD test $(\mathrm{P} \leq 0.05)$.

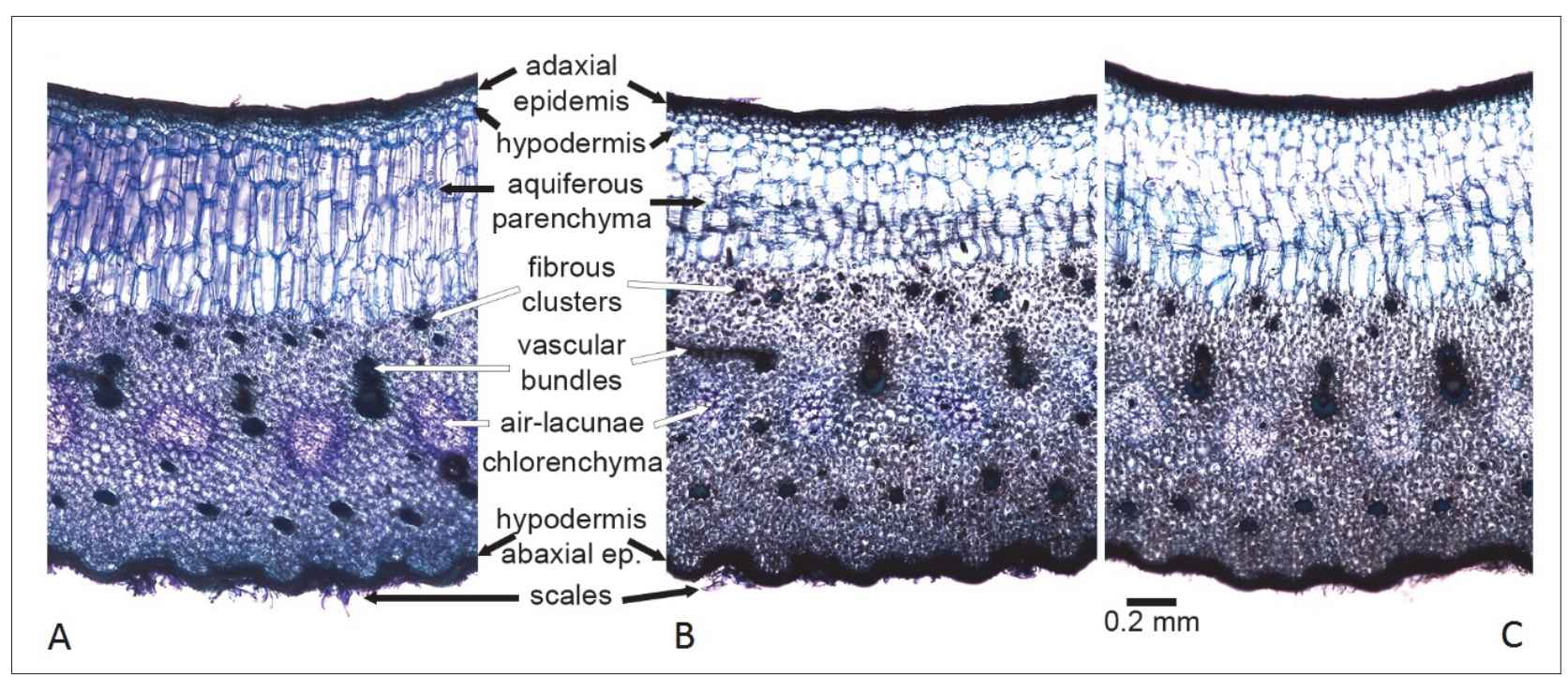

FiguRE 3. Cross sectional view of a 'D' leaf of pineapple at 45 days after applying the treatments Irrigation (A), Misting (B), and Drought (C).

TABLE 2. Percentage of aquiferous parenchyma (AqP) in 'Smooth Cayenne' pineapple plants at 0, 15, 30 and 45 days after applying the soil irrigation (I), misting (M) and drought (D) treatments. Means followed by the same letter in columns per treatment were not significantly different according to Tukey HSD test $(\mathrm{P} \leq 0.05)$.

\begin{tabular}{|c|c|c|c|c|c|}
\hline & \multirow{3}{*}{ Treatment } & \multicolumn{4}{|c|}{ Time } \\
\hline & & Day 0 & Day 15 & Day 30 & Day 45 \\
\hline & & Mean \pm SD & Mean \pm SD & Mean \pm SD & Mean \pm SD \\
\hline \multirow{3}{*}{$\% A q P$} & D & $44 \pm 1 a$ & $47 \pm 1 \mathrm{a}$ & $44 \pm 1 a b$ & $42 \pm 1 b$ \\
\hline & M & $44 \pm 1 \mathrm{a}$ & $45 \pm 2 a$ & $42 \pm 2 a$ & $36 \pm 2 a$ \\
\hline & I & $44 \pm 1 a$ & $46 \pm 1 a$ & $45 \pm 1 b$ & $51 \pm 1 c$ \\
\hline
\end{tabular}



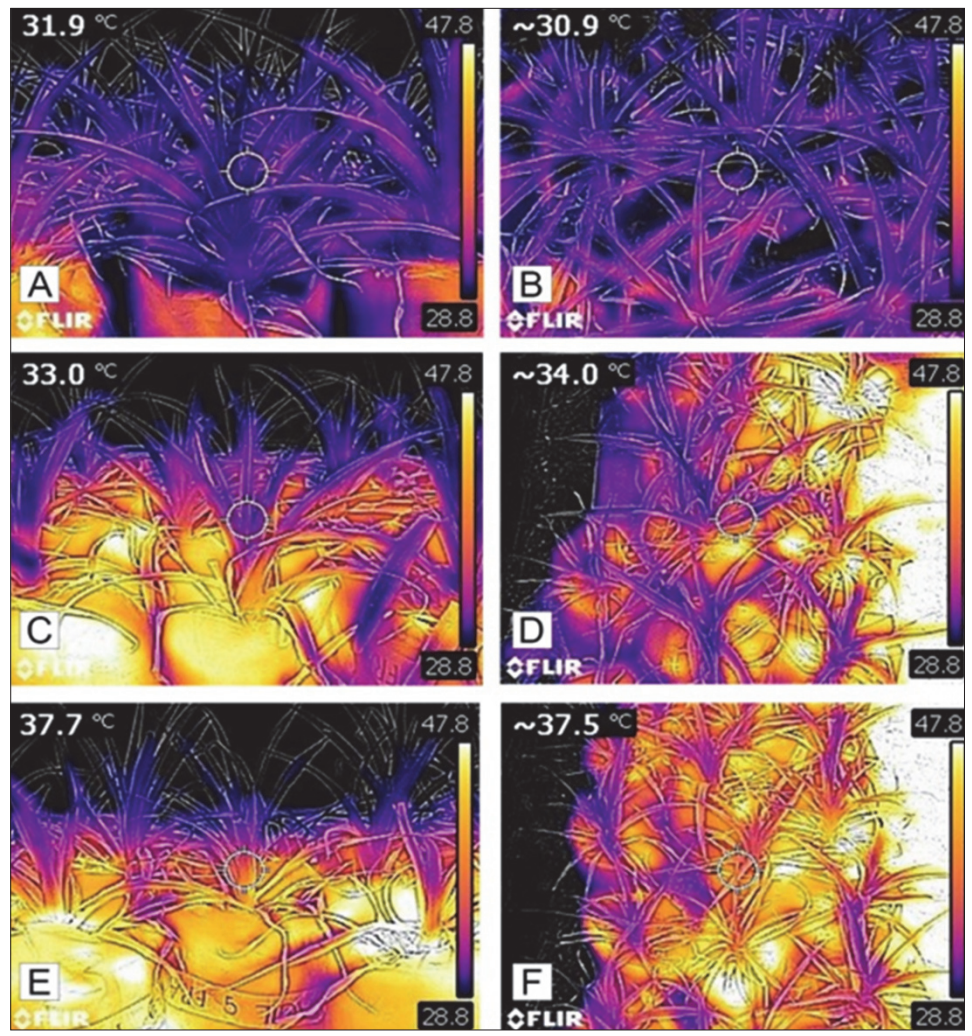

FigurE 4. Thermal images of 'Smooth Cayenne' pineapple plants taken at 45 days after applying Soil irrigation (A, B), Misting (C, D) or Drought $(\mathrm{E}, \mathrm{F})$ treatments. Leaf temperatures are shown.

\section{Discussion}

Pereira et al. (2013) found a high positive correlation between the leaf chlorophyll index (LCI), measured with a SPAD meter, and the total chlorophyll content, indicating that the SPAD meter can substitute for traditional determinations of actual chlorophyll content (Pereira et al., 2013). In a study of three pineapple cultivars, Rebolledo et al. (2002) found no significant difference in the LCI between field-grown plants and plants grown in protected culture with soil plastic mulch. We observed that the LCI in the Soil Irrigation treatment increased throughout the experimental period, similar to the results obtained by Ebel et al. (2016). However, plants in the Misting and Drought treatments did not follow this pattern, probably due to water stress inhibiting chlorophyll development. The maintenance of high chlorophyll content indicates a low degree of high temperature damage to the photosynthetic apparatus (Talebi, 2011).

The Normalized difference vegetation index (NDVI) estimates the quantity, quality, and development of vegetation based on the measurement of the intensity of radiation at wavelengths of the electromagnetic spectrum emitted or reflected by vegetation. A widely accepted non-destructive method of monitoring plant growth and development is to compare the amount of energy reflected from crops in the red and near infrared wavelengths (Mazzetto et al., 2009). The amount of incident light absorbed and reflected at different wavelengths has been used to develop vegetative indices that are sensitive to different environmental and physiological variables (Hatfield et al., 2008). The LCI and NDVI have been used as indicators of stress tolerance (Mason et al., 2011). High LCI and maximum NDVI are associated with tolerance to hydric and thermal stresses (Ramya et al., 2015; Munjal and Dhanda, 2016). The NDVI has been most widely used in drought monitoring, where it is generally reduced as a result of drought stress (Wang et al., 2010). For example, when barley was subjected to water stress, NDVI decreased (McKenzie et al., 2009). In the present study, the decreased NDVI in the Misting and Drought treatments indicates that pineapple plants are stressed by 15 days of no water (Drought treatment) or water supplied only by misting the leaves (Misting treatment). The NDVI has also been used successfully in pineapple to reliably predict the severity of red tip disease (Balasundram et al., 2013). The application of this technique can be very valuable in plant breeding for the selection of drought tolerant plants (Winterhalter et al., 2011). It should be noted that up to now, there is no record of the use of the NDVI as an indicator of drought stress in pineapple.

The relative water content (RWC) of plants in the Soil Irrigation treatment was typical for pineapple plants (Ebel et al., 2016). Despite the references that indicate trichomes at the base of pineapple leaves play an important role in water absorption (Py, 1969), in the present study it was observed that plants with water absorption only through the leaves (Misting treatment) were not able to maintain an adequate RWC. Plants with crassulacean acid metabolism (CAM), such as pineapple, can lose up to $80-90 \%$ of their RWC and still survive long periods without irrigation or rain. They also have the ability to prevent the reverse flow of water from their storage tissues to the ground (Carr, 2012). Under severe stress, a reduction in RWC is a common response. The RWC can be an indicator of water potential since the values of RWC and water potential behave similarly under conditions of water restriction (Alvarez et al., 2018). Cultivars of wheat exposed to drought that maintained the same or only a slightly decreased RWC were determined to be drought-resistant (Keyvan, 2010). Thus, comparisons of RWC of different pineapple cultivars could be indicative of resistance to water stress.

The rupture and damage of the cell membrane causes the loss of electrolytes (amino acids, organic acids, proteins, and other solutes). This loss represents damage to the cell mem- 
brane, and therefore is an important factor in plant stress tolerance. Both drought and thermal stress have similar effects on plant cells, damaging the selective permeability of the plasma membrane caused by an uncontrolled increase of free radicals (Moussa et al., 2008). Sullivan (1972) developed a test to measure heat tolerance, which determines the thermostability of the cell membrane by measuring the amount of electrolytes lost in leaf discs after exposure to a heat treatment $\left(>40{ }^{\circ} \mathrm{C}\right)$. The measurement of solute leakage from plant tissue was used to estimate cell membrane damage caused by different stress conditions in cereals under field conditions (Suzuki et al., 2014; Jamali et al., 2015; Wang et al., 2016). At the end of this experiment, the water applied by Misting was not as efficient as the Soil Irrigation in order to prevent the rupture and damage of the cell membrane.

The effects of water application treatments on total leaf area of pineapple observed in the present study agree with those reported by Bonnet Pérez and Ferrero (2012) in relation to the importance of adequate water supply through irrigation. Water deficiency leads to a severe decrease in yield, probably due a reduction of leaf gas exchange, which not only causes a limitation in the size of sink tissues, but also reduces phloem loading, translocation of assimilates, and the partitioning of dry matter (Farooq et al., 2009). Water stress inhibits the production of dry matter due to the inhibitory effect on foliar expansion, foliar development, and a concomitant decrease in light interception (Nam et al., 1998). González Leguizamón et al. (2013) found that the root development of pineapple plants, grown inside greenhouse (conditions of high relative humidity) during the first 7 months, was detrimental to stem reserves, while in the field-grown plants (drier conditions) the source for the destination roots were the leaves. The similarity in the PA for all the treatments after 45 days may be due to the fact that this is a very short period in terms of the development of pineapple plants.

Krauss (1949) determined that the ' $D$ ' leaves of pineapple plants have a curved contour with a smooth adaxial surface and an abaxial surface that has ridges. Both surfaces are covered by peltate scales that are more abundant on the underside. In transversal views, both epidermises are uniestrata, with the hypodermis formed by cells with strongly sclerified walls located below both epidermises. The stomata are only found in the abaxial surface. The mesophyll is dorsiventral, with two clearly differentiated zones: toward the adaxial surface it presents a clear area composed of aquiferous parenchyma and towards the abaxial surface is an area formed by compact chlorophyll parenchyma. The aquiferous parenchyma is heterogeneous; it has rounded and small cells in contact with the hypodermis that is elongated towards the inside of the mesophyll. In the chlorophyll zone where the vascular bundles are divided into large and small bundles that are alternately located; large bundles have periphloematic and perixylematic fibrous caps, with the latter being absent in small bundles. Alternating with the bundles, slightly displaced towards the lower part, are aeriferous cavities formed by stellate cells with short arms. In the limit between aquiferous and chlorophyll parenchyma are bundles of extra-thin fibers, not associated with vascular tissues, formed by fibers of lignified walls and completely occluded lumen. Between the vascular bundles and the abaxial epidermis there may be one or two rows of these same fibrous bundles (Figure 3). According to Bartholomew et al. (2002), when pineapple plants approach the wilting point, they can only continue living due to their water reserves constituted by the aquifer tissues of the leaves. When these are depleted, the first foliar wilt symptoms begin to appear.

In general, thick cuticle, water storage tissue, stomata localization, trichomes, and CAM metabolism contribute to the efficient water economy of pineapple (Coppens and Leal, 2003). The most sensitive indicator of water stress of the variables measured in the present study was the NDVI, which showed differences among treatments within 15 days. Ecophysiological, leaf anatomical, and growth responses of pineapple plants to irrigation solely from misting of the foliage (Misting treatment) were similar to those of plants with no water applied (Drought treatment), indicating the inefficiency of this terrestrial bromeliad species to absorb water through the foliage.

Many authors have proposed the use of thermal images of the canopy (Winterhalter et al., 2011; Neiff et al., 2015; Bai et al., 2016) to estimate water stress. We are aware of no previous report for the use of thermal images to assess water stress for pineapple, but it is expected that under severe stress leaf temperature increases. Although misting reduced leaf temperature, application of water to the soil with no misting, was just as effective as misting for reducing leaf temperature. Thus, high leaf temperature was presumably due to water stress and therefore could be alleviated solely by soil water application. During the day, the stomata are closed in CAM plants, thus limiting water loss by transpiration (Lobo et al., 2017). These results reject the hypothesis that the crop can receive sufficient irrigation to avoid plant stress solely from misting the foliage.

Based on ecophysiological, anatomical and growth responses, soil water application alone is sufficient for avoiding water stress and excessively high leaf temperatures of pineapple in protected culture in the subtropics, whereas only misting the leaves does not provide adequate water to prevent water stress.

\section{Acknowledgments}

This research was supported by the Secretaría General de Ciencia y Técnica de la Universidad Nacional del Nordeste, Corrientes, Argentina.

\section{References}

Álvarez, S., Rodríguez, P., Broetto, F., and Sánchez-Blanco, M.J. (2018). Long term responses and adaptive strategies of Pistacia lentiscus under moderate and severe deficit irrigation and salinity: Osmotic and elastic adjustment, growth, ion uptake and photosynthetic activity. Agric. Water Mgt. 202, 253-262. https://doi.org/10.1016/j. agwat.2018.01.006.

Bai, G., Ge, Y., Hussain, W., Baenziger, P.S., and Graef, G. (2016). A multi-sensor system for high throughput field phenotyping in soybean and wheat breeding. Computers and Electronics in Agric. 128, 181-192. https://doi.org/10.1016/j.compag.2016.08.021.

Balasundram, S.K., Kassim, F.A., Vadamalai, G., and Hanif, A.H.M. (2013). Estimation of red tip disease severity in pineapple using a non-contact sensor approach. Agric. Sci. 4(04), 206-208. https:// doi.org/10.4236/as.2013.44029.

Bartholomew, D.P., Paull, R.E., and Rohrbach, K.G. (eds.) (2002). The Pineapple, Botany, Production and Uses. (Wallingford, U.K.: CABI Press). https://doi.org/10.1079/9780851995038.0000.

Bonet Pérez, C., and Guerrero Posada, P.A. (2012). Evapotranspiración de la piña (Ananas comosus L. Merr.). Rev. Ingen. Agríc. 2(2), 36-41.

Botella, J.R., and Smith, M. (2008). Genomics of pineapple, crowning the king of tropical fruits. In Genomics of Tropical Crop Plants, P.H. Moore, and M. Ray, eds. (New York: Springer). 
Carr, M.K.V. (2012). The water relations and irrigation requirements of pineapple (Ananas comosus var. comosus): A review. Experim. Agric. 48(4), 488-501. https://doi.org/10.1017/S0014479712000385.

Carvalho, S.D., Neves, C.S.V.J., Bürkle, R., and Marur, C.J. (2005). Épocas de indução floral e soma térmica do período do florescimento à colheita de abacaxi 'Smooth Cayenne'. Rev. Brasil. de Fruticult. 27(3), 430-433. https://doi.org/10.1590/S0100-29452005000300022.

Coppens d'Eeckenbrugge, G., and Leal, F. (2003). Morphology, anatomy and taxonomy. In The Pineapple, Botany, Production and Uses, P.E. Bartholomew, R.E. Paull, and K.G. Rohrbach, eds. (Wallingford, U.K.: CABI Press). https://doi.org/10.1079/9780851995038.0013.

Derwidueé, F.S., and González, A.M. (2010). Anatomía foliar en Bromeliaceae del Nordeste Argentino y Paraguay. Bonplandia 19(2), 153-173.

Di Rienzo, J.A., Casanoves, F., Balzarini, M.G., González, L., Tablada, M., and Robledo, C.W. (2012). InfoStat versión 2012. Grupo InfoStat, FCA, Universidad Nacional de Córdoba, Argentina. http://www.infostat.com.ar.

Ebel, A.I., Gonzalez, A.M.. and Alayón Luaces, P. (2016). Evaluación morfoanatómica de hojas "D" de piña (Ananas comosus (L.) Merr. var. comosus) en respuesta a la implantación de dos sistemas de cultivo en Corrientes, Argentina. Acta Agronómica 65(4), 390-397.

Farooq, M., Wahid, A., Kobayashi, N., Fujita, D., and Basra, S.M.A. (2009). Plant drought stress: effects, mechanisms and management. Agron. Sustain. Dev. 29, 185-212. https://doi.org/10.1007/978-90481-2666-8_12.

González Leguizamón, R., Chabbal, M., Dominguez, J.F., Mazza, S., and Alayón Luaces, P. (2013). Ciclo vegetativo de plantas de ananás (Ananas comosus (L.) Merr.) bajo dos sistemas de cultivo en Corrientes. Facena 29,11-22. https://doi.org/10.30972/fac.290871.

Hatfield, J.L., Gitelson, A.A., Schepers, J.S., and Walthall, C.L. (2008). Application of spectral remote sensing for agronomic decisions. Agronomy J. 100, S117-S131. https://doi.org/10.2134/ agronj2006.0370c.

Jamali, S.S., Borzouei, A., Aghamirzaei, M., Khosronejad, H.R., and Fathi, M. (2015). Cell membrane stability and biochemical response of seven wheat cultivars under salinity stress. Brazil. J. Botany 38(1), 63-69. https://doi.org/10.1007/s40415-014-0123-9.

Keyvan, S. (2010). The effects of drought stress on yield, relative water content, proline, soluble carbohydrates and chlorophyll of bread wheat cultivars. J. Anim. Plant Sci. 8(3), 1051-1060.

Krauss, B.H.(1949). Anatomy of the vegetative organs of the pineapple, Ananas comosus (L.) Merr. (continued) II. The leaf. Botanical Gazette 110(3), 333-404. https://doi.org/10.1086/335540.

Lobo, M.G., and Paull, R.E. (2017). Handbook of Pineapple Technology: Production, Postharvest Science, Processing and Nutrition, E. Robert, ed. (Chichester, UK: John Wiley \& Sons). https:// doi.org/10.1002/9781118967355.

Martin, C.E. (1994). Physiological ecology of the Bromeliaceae. Botanical Rev. 60(1), 1-82. https://doi.org/10.1007/BF02856593.

Mason, R.E., Mondal, S., Beecher, F.W., and Hays, D.B. (2011). Genetic loci linking improved heat tolerance in wheat (Triticuma estivum L.) to lower leaf and spike temperatures under controlled conditions. Euphytica 180(2), 181-194. https://doi.org/10.1007/s10681-0110349-6.

Mazzetto, F., Calcante, A., and Mena, A. (2009). Comparing commercial optical sensors for crop monitoring tasks in precision viticulture. J. of Agric. Engin. - Riv. di Ing. Agr. 1, 11-18. https://doi. org/10.4081/jae.2009.1.11.

McKenzie, B.M., Bengough, A.G., Hallett, P.D., Thomas, W.T.B., Forster, B., and McNicol, J.W. (2009). Deep rooting and drought screening of cereal crops: A novel field-based method and its application. Field Crops Res. 112(2-3), 165-171. https://doi.org/10.1016/j. fcr.2009.02.012.

Moussa, H.R., and Abdel-Aziz, S.M. (2008). Comparative response of drought tolerant and drought sensitive maize genotypes to water stress. Austr. J. Crop Sci. 1(1), 31-36.

Munjal, R., and Dhanda, S.S. (2016). Assessment of drought resistance in Indian wheat cultivars for morpho-physiological traits. Ekin J. Crop Breeding Genet. 2(1), 74-81.

Nam, N.H., Subbarao, G.V., Chauhan, Y.S., and Johansen, C. (1998). Importance of canopy attributes in determining dry matter accumulation of pigeonpea under contrasting moisture regimes. Crop Sci. 38(4), 955-961. https://doi.org/10.2135/ cropsci1998.0011183X003800040013x.

Neiff, N., Dhliwayo, T., Suarez, E.A., Burgueno, J., and Trachsel, S. (2015). Using an airborne platform to measure canopy temperature and NDVI under heat stress in maize. J. Crop Improvement 29(6), 669-690. https://doi.org/10.1080/15427528.2015.1073643.

Pereira Leonardo, F.A., Pereira, W.E., de Melo Silva, S., and Pereira Da Costa, J. (2013). Teor de clorofila e Índice Spad no Abacaxizeiro cv. Vitória emfunção da adubação nitrogenada. Rev. Brasil. de Fruticultura 35(2), 377-383. https://doi.org/10.1590/S010029452013000200006.

Poczai, P., and Hyvönen, J. (2017). The complete chloroplast genome sequence of the CAM epiphyte Spanish moss (Tillandsia usneoides, Bromeliaceae) and its comparative analysis. PlosOne 12(11), e0187199. https://doi.org/10.1371/journal.pone.0187199.

Py, C. (1969). La Piña Tropical, Técnicas Agrícolas y Producciones Tropicales. (Barcelona, España: Editorial Blume).

Ramya, P., Jain, N., Singh, G.P., Singh, P.K., and Prabhu, K.V. (2015). Population structure, molecular and physiological characterisation of elite wheat varieties used as parents in drought and heat stress breeding in India. Indian J. Genet. Plant Breed. 75, 250-252. https:// doi.org/10.5958/0975-6906.2015.00038.3.

Rebolledo-Martínez, A.M., Ruiz-Posadas, L., Becerril-Román, A.E., Mosqueda-Vázquez, R., Castillo-Morales, A., Rebolledo-Martínez, L., and Uriza-Ávila, D. (2002). Algunas características fisiológicas de tres cultivares de piña en dos sistemas de producción. Rev. Chapingo Serie Hortic. 8(2), 235-249. https://doi.org/10.5154/r. rchsh.2001.11.081.

Rebolledo-Martínez, A.R., Ángel-Pérez, D., Lid, A., Becerril-Román, A.E., and Martínez, L.R. (2005). Growth analysis for three pineapple cultivars grown on plastic mulch and bare soil. Interciencia 30(12), 758-763.

Sakai, W.S., and Sanford, W.G. (1980). Ultrastructure of the waterabsorbing trichomes of pineapple (Ananas comosus, Bromeliaceae). Annals of Botany 46(1), 7-11. https://doi.org/10.1093/ oxfordjournals.aob.a085897.

Shen, T., and Chen, C. (2012). Misting cooling technique for protected culture of Oncidium orchids in subtropical regions. Afric. J. Biotechnol. 11(80), 14612-14620.

Sullivan, C.Y. (1972). Mechanisms of heat and drought resistance in grain sorghum and methods of measurement. In Sorghum in the Seventies, L.R. House, and N.G.P. Rao, eds. (New Delhi, India: Oxford and IBH Publ. Co.).

Suzuki, N., Rivero, R.M., Shulaev, V., Blumwald, E., and Mittler, R. (2014). Abiotic and biotic stress combinations. New Phytologist 203(1), 32-43. https://doi.org/10.1111/nph.12797.

Talebi, R. (2011). Evaluation of chlorophyll content and canopy temperature as indicators for drought tolerance in durum wheat (Desf.). Austral. J. Basic and Appl. Sci. 5(11), 1457-1462. 
Wai, C.M., Van Buren, R., Zhang, J., Huang, L., Miao, W., Edger, P.P., and Smith, J.A.C. (2017). Temporal and spatial transcriptomic and microRNA dynamics of CAM photosynthesis in pineapple. Plant J. 92(1), 19-30. https://doi.org/10.1111/tpj.13630.

Wang, W., Wang, W.J., Li, J.S., Wu, H., Xu, C., and Liu, T. (2010). The impact of sustained drought on vegetation ecosystem in Southwest China based on remote sensing. Proc. Environm. Sci. 2, 1679-1691. https://doi.org/10.1016/j.proenv.2010.10.179.

Wang, X., Zhang, M.M., Wang, Y.J., Gao, Y.T., Li, R., Wang, G.F., and Chen, K.M. (2016). The plasma membrane NADPH oxidase OsRbohA plays a crucial role in developmental regulation and drought-stress response in rice. Physiologia Plant. 156(4), 421-443. https://doi. org/10.1111/ppl.12389.

Winterhalter, L., Mistele, B., Jampatong, S., and Schmidhalter, U. (2011). High-throughput sensing of aerial biomass and aboveground nitrogen uptake in the vegetative stage of well-watered and drought stressed tropical maize hybrids. Crop Sci. 51(2), 479-489. https://doi.org/10.2135/cropsci2010.07.0397.

Received: Sep. 12, 2018

Accepted: Dec. 1, 2019 